\title{
Affirming a Role for Specialised Dictionaries in Indigenous African Languages*
}

\author{
Dion Nkomo, Department of Afrikaans and Dutch, University of \\ Stellenbosch, Stellenbosch and Multilingualism Education Project, Centre for \\ Higher Education Development, University of Cape Town, Cape Town, \\ South Africa (deeouf@yahoo.co.uk)
}

\begin{abstract}
One of the main problems facing speakers and language practitioners of indigenous African languages is the shortage of appropriate dictionaries for a variety of purposes. This lack results in users consulting any available but inappropriate dictionaries. Quite often, users are disappointed because a wrong dictionary does not normally provide the required assistance. Various functions, which the dictionary may serve, are sought in vain from inappropriate dictionaries and other terminological products. Consequently, the potential of lexicography in general and specialised lexicography in particular, remains unrealised owing to a variety of reasons. This article which mainly discusses the specialised dictionary, draws insights from Wiegand's (1984) general theory of lexicography and the theory of lexicographic functions (Bergenholtz and Tarp 1995, 2003; Tarp $2000,2002,2008)$ to affirm the role of specialised dictionaries in indigenous African languages and also to give insights into how such dictionaries may be produced.
\end{abstract}

Keywords: LEXICOGRAPHY, LSP LEXICOGRAPHY, METALEXICOGRAPHY, DICTIONARY HISTORY, DICTIONARY CRITICISM, DICTIONARY TYPOLOGY, DICTIONARY STRUCTURE, LSP DICTIONARY, AFRICAN LANGUAGES, LEXICOGRAPHIC FUNCTIONS

Opsomming: Die bevestiging van 'n rol vir gespesialiseerde woordeboeke in die inheemse Afrikatale. Een van die hoofprobleme waarvoor sprekers en taalpraktisyns van inheemse Afrikatale te staan kom, is die tekort aan gepaste woordeboeke vir 'n verskeidenheid doeleindes. Hierdie gebrek lei daartoe dat gebruikers enige bekombare maar ongeskikte woordeboeke raadpleeg. Heel dikwels word gebruikers teleurgestel omdat 'n verkeerde woordeboek nie normaalweg die verlangde hulp verskaf nie. Verskillende funksies wat die woordeboek kan aanbied, word tevergeefs in ongeskikte woordeboeke en ander terminologiese produkte gesoek. Gevolglik bly die potensiaal van die leksikografie in die algemeen en die gespesialiseerde leksikografie in die besonder onverwesenlik vanweë 'n verskeidenheid redes. Hierdie artikel wat hoofsaaklik die gespesialiseerde leksikografie bespreek, verkry insigte uit Wiegand (1984) se algemene teorie van die leksikografie en die teorie van leksikografiese funksies (Bergenholtz and Tarp 1995, 2003; Tarp 2000, 2002, 2008) om die rol van gespesialiseerde woordeboeke in die inheemse Afrikatale te bevestig, en ook om insigte te verskaf in hoe sulke woordeboeke gemaak kan word.

* This article is a revised version of a paper presented at the Fourteenth International Conference of the African Association for Lexicography, organised by the Xhosa Department, University of the Western Cape, Bellville, South Africa, 6-8 July 2009. 
Sleutelwoorde: LEKSIKOGRAFIE, TSD-LEKSIKOGRAFIE, METALEKSIKOGRAFIE, WOORDEBOEKGESKIEDENIS, WOORDEBOEKKRITIEK, WOORDEBOEKTIPOLOGIE, WOORDEBOEKSTRUKTUUR, TSD-WOORDEBOEK, AFRIKATALE, LEKSIKOGRAFIESE FUNKSIES

\section{Introduction}

Over the last four decades, at least two factors have had a huge impact on practical lexicography on a global level. The first was the use of computer technologies for language data storage and processing which improved the methodological aspects of dictionary-making. Computer technologies led to, among other outcomes, corpus-based lexicography, and made certain lexicographic tasks easier to undertake. The other factor is the contested development of lexicography into a fully-fledged discipline. This resulted from and in more research being conducted on dictionary making methods and dictionary use. Similarly, the ultimate endeavour has been the improvement of lexicographic practice.

Despite such developments on a global level, lexicographic practice in the indigenous African languages continues to face big challenges. These include the level of development of the languages and a young or even a non-existent dictionary culture. Many people in African communities still hold the view that they do not need lexicographic assistance regarding their native languages. This results in dictionaries in indigenous languages failing to be regarded as the utility tools they are meant to be. While this article argues that dictionaries in general have a very important role to play in the development, acquisition and use of indigenous African languages, it mainly focuses on specialised dictionaries (henceforth LSP dictionaries). In the indigenous African languages, the LSP dictionary genre has thus far received the least attention, with lexicographers, linguists and language planners giving more attention to general dictionaries, which are viewed as language standardisation and documentation tools. Thus more focus is on the documentation and preservation of the languages rather than on their use. When it comes to LSP dictionaries, several questions, including the following, are often raised:

- What would you call an atom in a Zulu dictionary?

- How are you going to define terms for specialised concepts in Shona?

- Why would you produce a Physics dictionary in Ndebele when Physics dictionaries are available in the languages of wider communication used in such specialised fields?

- Who needs specialised dictionaries African languages when the teaching of and practice in special subject fields are conducted in English?

The first two questions raise methodological concerns, implying that without effective strategies, LSP lexicography in indigenous African languages is 
doomed to fail or result in the production of substandard lexicographic products. To this extent these concerns are genuine. Unfortunately, they are limited in that they are motivated by an English-biased linguistic orientation which purports that African languages are incapable of handling specialised knowledge. The other two questions are more critical, because they query the very essence of lexicographic practice. If no one needs LSP dictionaries and reasons do not exist for their production, then they should not be discussed as they would serve no useful purpose. The status and functional elevation of indigenous African languages is seen as a precondition for the production and relevance of LSP dictionaries and other reference tools. However, that the speakers of indigenous languages do not need LSP dictionaries in their own languages simply because English is the main language used in specialised fields is problematic. It assumes that in the context of English dominance, the second and third language speakers of English do not rely on their native languages to conceptualise, develop and/or communicate specialised knowledge. Drawing insights from the theory of lexicographic functions (Bergenholtz and Tarp 1995, 2003; Tarp 2000, 2002, 2005, 2008, 2010), this article seeks to demonstrate that LSP dictionaries in indigenous African languages can play a very significant role in the teaching and practice of various subject fields in which English is currently the main medium of communication. However, role should not be confused with function as defined in the theory of lexicographic functions. Instead, in this article, the role of LSP dictionaries is seen as a collective of lexicographic functions, which the dictionaries may serve, thereby affirming their relevance.

\section{In defence of lexicography}

In order to put our argument into perspective, it is important to underline the fundamental principles of lexicography which constitute its core as a discipline and separate it from other disciplines, particularly linguistics. From the outset, which is traced back to around 4000 years ago, lexicography has developed as a problem-solving activity (Al-Kasimi 1977, McArthur 1986, Gouws and Prinsloo 2005, Bergenholtz and Tarp 2003, Tarp 2008). This history has earned dictionaries, the most typical lexicographic products, a prestigious regard as utility products (Wiegand 1984, Bergenholtz and Tarp 2003, Tarp 2000, 2008) and containers of knowledge (McArthur 1986). In the course of the history of lexicography until now, not all dictionaries have successfully fulfilled these fundamental principles. Thus the development of metalexicography has had dictionary criticism as one of its constituent parts (Wiegand 1984: 15). However, dictionary criticism has not always been undertaken within a lexicographically motivated model, with Swanepoel (2008: 208-209) arguing that it generally lacks objectivity, validity and reliability, and Béjoint (2000: 113) observing that quite often it amounts to 'dictionary bashing'. Accordingly, most dictionary criticism has failed, according to Swanepoel (2008: 209), to: 
(1) assist readers in their decision-making in acquiring the best dictionaries for their usage needs by presenting them with a well-founded analysis of the positive and negative qualities of a dictionary/dictionaries under review, and (2) assist lexicographers in optimizing the functionality of their dictionaries.

In short, dictionary criticism needs to be consistent with the principles of lexicography. It should not be seen as an end in itself but a means towards the production of functional and more user-friendly dictionaries.

Likewise, it is important to recall that lexicography emerged as a practical activity with the objective of producing utility tools rather than developing theories. Dictionaries were first compiled in a pre-theoretical environment. The theoretical component of lexicography, according to Gouws and Prinsloo (2005: 1 ), can be regarded as "a relative late-comer because lexicography has originally been associated with the practice of dictionary-making". Metalexicography, or theoretical lexicography, has been developed to enable lexicographic practice (cf. Gouws and Prinsloo 2005: 1, Tarp 2008: 11). Such a development has been welcomed, in the hope that it would ensure the production of functional, appropriate and user-friendly dictionaries to keep users abreast of the demands of the information age.

Whereas lexicographic practice has not generally faced direct opposition, it is the establishment of lexicography as a discipline and the development of the relevant theories which have been strongly contested over the years (cf. Sinclair 1984, Atkins and Rundell 2008: 4, Béjoint 2010: 381, Tarp 2010). This has had serious consequences for the development and appreciation of dictionaries as utility products. As a rule rather than an exception, poor dictionaries have been seen as representative of lexicography and its potential. Accordingly, the affirmation of a role for LSP dictionaries in the indigenous African languages should not be viewed in isolation but in a rather broader framework of defending lexicography as a professional and scientific discipline in which practice and theory ought to accompany each other to produce functional ena userfriendly dictionaries. In turn, this makes it important to highlight how lexicography has been unwittingly undermined in academic circles through subjective dictionary criticism. A case in point is an article by Moropa (2004) who appraises a parallel corpus as a terminology resource for Xhosa which, however, amounts to a criticism of lexicography rather than a few selected dictionaries which fail to support translation. She begins by quoting from Pinchuck (1977) that no bilingual dictionary is ever perfect, a very simple fact which metalexicography has demonstrated in respect of all dictionary genres. Competent dictionary users would be satisfied by consulting an appropriate and good dictionary, be it monolingual or bilingual. Because no bilingual dictionary is ever perfect, Moropa (2004: 164) then advises:

When attempting to find an equivalent, a translator would do better to consult a good monolingual dictionary in the source language and also a good monolingual dictionary in the target language, if necessary. In many cases the bilingual dictionary does not supply the most suitable translation equivalent for a certain 
context, but it does supply a collection of expressions in the target language from which the user must make a choice. The translator may use the equivalents as guidelines at most. The bilingual dictionary also tends to furnish standardised translations that do not correspond to the full lexical range in the two languages and may therefore be incorrect because of shifts of meaning in both languages. A bilingual dictionary should be used only as a last resort.

This quotation contains statements which have negative implications for lexicography. Such views of the limitations of dictionaries in fulfilling specific needs experienced by certain users in specific situations are not peculiar to Moropa (2004) but shared by many linguists and language practitioners. For example, the statements contained in the above quotation are reminiscent of Bowker and Pearson (2002) who raise the following questions:

How often do you have to consult more than one dictionary in order to find the information you are seeking? How often do you find that the information you are seeking is simply not there? How often do you choose a word in the dictionary without really knowing whether it is the right one?

... no single dictionary will ever provide you with all the information you require ...

It cannot be denied that users may find certain dictionaries deficient as far as certain user needs are concerned, but the implication that dictionaries have no potential to address these needs is quite wrong. It is in this respect that lexicographers and metalexicographers need to clarify certain lexicographic issues which are often discussed on the sidelines of the discipline to improve the awareness of lexicographic products and their roles. Issues such as dictionary typology and dictionary functions are not taken into account in the cited criticism of dictionaries. Accordingly, the following statements are made to defend lexicography, but not specifically the dictionaries criticised by Moropa (2004), although it would even emerge that the dictionaries are unfairly criticised.

- Not every interlingual dictionary is a bilingual or multilingual dictionary. Some dictionaries are regarded as bilingual simply because they provide translation equivalents, but translation equivalents do not elevate a dictionary to the status of bilingual dictionaries (cf. Gouws 2004: 268-269, Burkhanov 2004: 17).

- Not every bilingual or multilingual dictionary is a translation dictionary (cf. Burkhanov 2004: 22, Tarp 2002a). To criticise any bilingual dictionary for not providing all the data categories required to aid translation is only justified if its compiler(s) aimed at producing a translation dictionary. However, it may be possible and economic to integrate the translation function in one bilingual dictionary thereby making it polyfunctional.

- While a bilingual dictionary may provide "a collection of expressions in the target language from which the user must make a choice", it may 
also provide data categories which guide users in selecting appropriate translation equivalents in various contexts. Collocations and sense discriminators are good examples (Al-Kasimi 1977: 67-75, Mafela 2005: 275285, Yong and Peng 2007: 204).

- Proscriptive lexicography now bridges prescriptive and descriptive lexicographic approaches (cf. Bergenholtz 2003, Tarp and Gouws 2008) to address linguistic and cultural anisomorphism in bilingual dictionaries.

These points are counter-arguments against the assertion that "a bilingual dictionary should be used only as a last resort" (Moropa 2004: 164). This should not be asserted as a rule because it is based on the inadequacy of selected dictionaries regarding the translation of financial texts. It is even unfair to criticise the dictionaries on the basis that they do not support the translation of financial texts, because none of the dictionaries seem to have been compiled specifically to assist users with the translation of financial texts as one of its functions. They are neither dictionaries of business, finance, commerce or economics. For example, in a preface that has been reproduced in the successive reprints of the English-Xhosa Dictionary, Fischer et al. (1985) clarify:

The idea for this English-Xhosa Dictionary was conceived during many years of studying and teaching Xhosa, being confronted with the lack of an appropriate English-Xhosa dictionary. When the foundation for the dictionary was laid in 1975 it was planned as a small handbook, aimed at the English-speaking student learning Xhosa ...

We started to expand the entries, trying to meet the needs of the English-speaking student to master Xhosa, and to cover the needs of the Xhosa-speaking student confronted with essay and literature in the English curriculum.

This indicates that this dictionary, which happens to be the best available dictionary to use when translating from English to Xhosa, was primarily compiled to support second language learning. To expect general bilingual dictionaries to achieve a fair coverage and treatment of business LSP is, therefore, to ask for too much. It is a biased way of advancing the argument for a parallel corpus as a terminology resource, because it conveniently ignores the fact that the corpus referred to is a specialised one, i.e. consisting of financial texts. The challenges of building such corpora for an African language such as Xhosa, given translation challenges, some of which are reflected in Madiba (2004) in the form of the inconsistent use of particular legal terms in a Venda version of the constitution of South Africa, are also ignored. Some of the challenges could be effectively overcome if good quality translation dictionaries or LSP dictionaries with a translation function were available. For the purpose of the main argument of this article, one finds Moropa's (2004) article useful in demonstrating that African communities do not have appropriate dictionaries for the translation of specialised texts into African languages. Provided with well-conceived translation dictionaries, professional translators would appreciate the value of dic- 
tionaries in their practice. Just like parallel corpora (Madiba 2004, Moropa 2004), LSP dictionaries in indigenous African languages need to be seen as potentially useful tools and resources which may solve problems faced in the development and acquisition of specialised languages as well as the translation of specialised texts. Instead of dismissing one type of product to argue for another, it would be more advantageous to argue for the complementary use of different tools and the elimination of their individual shortcomings. What should always be borne in mind are the challenges of developing such tools and, in view of such challenges, theoretical models need to be devised to ensure that user-friendly products are produced. In this article, the focus will only be on LSP lexicography.

\section{Challenges for LSP Lexicography in the African Languages}

\subsection{Language policies}

The language policies of most African nations are unfavourable to LSP lexicography as they assign very restricted roles to indigenous languages. For example, in Zimbabwe, English still dominates both the public and private sectors. Indigenous languages are used sparingly as in courts where they are only accommodated with the aid of interpreters or in education prior to the fourth grade. There is a general paucity of resources and tools designed to support the use of the indigenous languages for these limited roles, so much so that the languages are often deemed deficient in communicating specialised knowledge. This means that instead of expanding their functional area, indigenous languages continue losing more ground to English. Perhaps the unavailability of language resources and tools may be seen as one serious handicap in the implementation of South Africa's multilingual national language policy in which indigenous languages are accommodated as official languages. It is unfortunate that such unavailability is often used as the reason for not implementing policies which promote indigenous languages instead of being used to motivate the development of the relevant tools. In the case of lexicography, LSP dictionaries in English continue to be the problem-solving instruments since the problems which have to be solved will usually be encountered in English which is used in those specific situations involving specialised knowledge. There are, however, situations in which LSP dictionaries in indigenous African languages would be useful for at least providing certain information such as equivalents in indigenous languages. It is only when the situations are concretised that the value of LSP dictionaries in African languages may be acknowledged, and this can be done within a metalexicographically-motivated model.

\subsection{Theoretical problems}

In African countries, there are several projects that are being undertaken on 
individual or institutional level to develop the indigenous languages, particularly their terminologies. Most of them lack clear identification and theoretical guidance. However, what clearly emerges from the majority of them is such a strong lexicographic fear that they have painstakingly, though vainly, tried to avoid any association with the term lexicography. Rather, the terms terminology development and terminography are preferred. While they actually develop terminology, usually by collecting and creating terms, the description and treatment of these terms in preparation for dissemination seem to borrow selectively from lexicography. The preferred term for the intended products is glossaries, for the sole reason that the products are limited in range and information. Such criteria for distinguishing between glossaries and LSP dictionaries are largely arbitrary. For example, while Bowker and Pearson (2002: 139) criticise dictionaries, it is remarkable that what they regard as the advantages of glossaries (Pearson and Bowker 2002: 138) and data types contained by glossaries (Pearson and Bowker 2002: 160) also apply to LSP dictionaries. In fact, the majority of those practitioners who prefer the production of glossaries over LSP dictionaries, despite the fact that the distinction between them is not clear, seem to opt for a minimalist approach towards the treatment of LSP. Such an approach reflects an evasion of what they regard as tedious lexicographic processes and incomprehensible lexicographic theories (cf. Tarp 2010). Unfortunately, equally minimal is the assistance provided by the end products. This only vindicates those scholars who argue that the distinction between terminology development/terminography on one hand and LSP lexicography on the other is of no practical use, because a large area of confluence exists between them (Bergenholtz and Nielsen 2006: 282-285, Fuertes-Olivera and ArribasBaño 2008: 8, Tarp 2000: 190). Hartmann (2005: 85) with good reason calls for mutual respect rather than the love-hate relationship which exists between lexicography and other disciplines with which it has contact. This would facilitate the production of user-friendly products, regardless of whether they are called glossaries or LSP dictionaries.

\section{A theoretical model for LSP lexicography in African languages}

A theoretical model is needed to help lexicographers identify problems which may be solved by LSP dictionaries. The model will also help in the prioritisation, planning and actual compilation of the dictionaries. More importantly, it should also ensure that the produced dictionaries are functional and userfriendly. The model proposed here is a complementary appropriation of Wiegand's (1984) general theory of lexicography and the theory of lexicographic functions developed by (meta)lexicographers at the Aarhus School of Business in Denmark. This is a cautiously conciliatory undertaking, given the less convincing suggestion by Bergenholtz and Tarp (2003) that Wiegand's general theory of lexicography and the theory of lexicographic functions are opposing theories (cf. Nkomo 2008). 


\subsection{Wiegand's general theory of lexicography}

Wiegand's general theory of lexicography is part of metalexicography (the total metadomain of lexicography or dictionary research), alongside the history of lexicography, research on dictionary use and criticism of dictionaries (Wiegand 1984: 15). Over the years, the appraisal of this theory has been undertaken by various scholars (e.g. Smit 1996, 1998, 2002; Gouws 2001; Gouws and Prinsloo 2005) and will not be repeated here. Only a demonstration of how it may provide a general framework for LSP lexicographic practice in African languages is offered.

The four sections of the theory, namely the general section (purposes of dictionaries, relationships to other theories, principles from the history of lexicography), theory of organisation, theory of lexicographic research on language (data collection, data processing, computer assistance) and theory of the lexicographic description of language (dictionary typology and textual theory for lexicographic texts), need to be taken into account in order to facilitate the production of dictionaries in view of an interplay of factors in a particular lexicographic setting. In this case, African communities are regarded as lexicographic scenes within which LSP lexicography in the indigenous languages needs a clear justification based on the functional role which the dictionaries may serve. It is noteworthy that Wiegand's theory has already inspired LSP lexicographic research in African countries such as South Africa (Smit 1996, 1998), Zimbabwe (Nkomo 2008) and Gabon (Ella 2007). The application of some elements of the theory to determine the role of LSP dictionaries in African languages is discussed in the following subsections.

\subsubsection{The relationships of lexicography with other theories}

This aspect, which falls under what Wiegand (1984: 15) calls the general section, becomes relevant in the consideration of lexicography and its interdisciplinary contacts, also discussed by scholars like Tarp $(2000,2002,2010)$ and Hartmann (2005). Theories in fields such as terminology, translation, language teaching and applied linguistics, among others, should be mentioned. So far, LSP lexicography in the African languages has involved a great deal of termcreation as can be illustrated by the compilation of the Shona biomedical terms dictionary, the Shona linguistic and literary terms dictionary, and the Shona and Ndebele music terms dictionary in Zimbabwe, as well as the production of Isichazi-magama seziBalo Sezikolo in South Africa. The reason for this is the acknowledged problem of a lack of terminology in the African languages. In view of this, terminological theories also need to be considered by lexicographers who want to compile LSP dictionaries of acceptable linguistic, terminological and lexicographic standards. What for a long time has been regarded as the fundamental differences between terminography and lexicography has been found to be invalid and of no practical use (Bergenholtz and Nielsen 2003: 
282-285, Fuertes-Olivera and Arribas-Baño 2008: 8). In fact, LSP dictionaries may prove to be effective standardisation and dissemination tools for terminology. Yet again, translation theories will always come into play given the fact that terminology has to be developed by, among other means, translation and also that LSP dictionaries will need to consider translation as one of their functions. Language teaching theories will have to be considered so that LSP dictionaries may play a practical role in helping users with the acquisition of the LSPs of certain subjects in both English and the indigenous languages.

\subsubsection{The history of lexicography}

In African language communities, LSP lexicography, just like general lexicography, may be inspired by the fact that lexicography evolved as a problemsolving enterprise in the lexicographic history of specific communities or languages. In Africa, this history is characterised by an acute shortage of particular dictionary genres (with LSP dictionaries being the scarcest), dictionaries whose production was determined by the limited roles of African languages, dictionaries which display certain supremacist attitudes and dictionaries which were compiled without paying attention to the needs and skills of the users (cf. Awak 1990: 10, Busane 1990: 20, Chabata 2007: 280, Gouws 1996: 99, Nkomo 2008: 10). Many socio-economic, political, cultural and religious changes have since taken place. Globalisation has exerted its influence whereby knowledge development, knowledge acquisition and knowledge dissemination necessitate communication which cuts across all kinds of barriers. In such a context, many changes in the lexicographic scenes of Africa are required. These include the production of various dictionary genres for different purposes. The LSP dictionary genre is one important type in this context and, as in the past, it has to deal with the challenges of the day. For example, because of the improved status of African languages and the need to improve it further, in Zimbabwe and South Africa, LSP lexicography has already begun and should continue with the desired expansion of functional space for the indigenous languages.

\subsubsection{The theory of organisation}

Elaborating on Wiegand's (1994) metalexicography, Smit (1996: 105) states that the purpose of the theory of organisation is to determine the basic rules for organising all the areas of lexicographic activities. It starts from general planning to the eventual publication of a dictionary. Thus, the publication of a dictionary is the culmination of a much more comprehensive set of activities, the so-called lexicographic process (Gouws and Prinsloo 2005: 9).

The organisational structure of the South African lexicographic setting is such that dictionary production may follow an ideal lexicographic process with hierarchical agents responsible for the planning and compilation of dictionaries. At the apex is the Pan South African Language Board (PanSALB) which is 
responsible for what is called a primary comprehensive lexicographic process. This concerns long-term strategic planning, support, supervision and coordination of lexicographic activities with other stakeholders in lexicographic practice such as the National Lexicography Units (NLUs) and publishers. Part of the activities of the NLUs and the National Language Service (NLS) would constitute a secondary comprehensive process while others would constitute what could be called specific lexicographic processes. Since the NLUs focus on specific languages while the NLS mainly focuses on specialised language, as part of a secondary lexicographic process, their tasks involve planning at institutional level. This entails resource allocation to different lexicographic projects within an institution. In the case of the NLS it also entails the prioritisation of some projects over others in view of the lexicographic needs in a particular language or subject area. Specific lexicographic processes ultimately focus on specific lexicographic projects, their planning and actual execution. They concern dictionary-specific issues.

The conception of such a set-up, in which the government pledged commitment and support, was based on the recognition of the potential of lexicography in addressing various language-related problems and furthering the ideals of the country's multilingual language policy (Gouws 2003: 224-225). It would appear that this could be realised when the country's officially recognised languages were equipped with different types of dictionaries and when these dictionaries were produced according to the prioritisation of the needs of the language speakers. Reflecting the ideals of the theory of organisation, the South African set-up would ensure that lexicographic practice is undertaken in a coordinated way.

In line with the neatly planned hierarchical structure of the South African lexicographic processes, the NLS has created a few products such as the Multilingual Mathematics Dictionary to assist primary school learners. However, the South African lexicographic scene has more products of this nature independently created by publishers, notably the Oxford Mathematics and Science Dictionary series for schools. Cambridge University Press also published Wababa, Welman and Press's Isichazi-magama seziBalo Sezikolo early in 2010. Yet again, various institutions of higher education such as the Stellenbosch University's Unit for IsiXhosa and the University of Cape Town's Centre for Higher Education, among others, are engaged in the compilation of glossaries intended to help students in learning specialised concepts and LSPs of specialised subject areas. There are many such activities which result in products whose compilers normally call them glossaries or learning and teaching resource books, such as Young et al. $(2005,2009)$ rather than dictionaries. Notably, the purposes for undertaking the creation of such products may be fulfilled effectively if lexicographic guidance is sought to avoid duplication of efforts and to ensure userfriendliness of the products. The lack of the application of lexicographic theories leads to a failure to exploit all the opportunities for providing the target users with optimum assistance. For example, what most of these glossaries, as 
they are called, do is to list English terms and provide them with only translation equivalents and at times brief explanations in both English and the indigenous languages. This gives very little help to users, be it for communication or cognitive purposes. More unsatisfactory is that there is very minimal collaboration between the involved individuals and institutions. This poses the danger of the duplication of efforts, and also competition, although this is not necessarily objectionable as long as linguistic communities are provided with appropriate and user-friendly dictionaries.

\subsubsection{Theory of the lexicographic description of language}

Under this component of metalexicography, Wiegand (1984: 17) considers dictionary typology and dictionary structure. These are important elements of a lexicographic theory which marked a departure from a largely linguistic approach to lexicographic practice. For example, it became apparent that instead of dwelling exclusively on the availability of certain linguistic elements in a dictionary, it was also important to consider the accessibility of data and retrievability of information. However, dictionary typology has always been problematic while dictionary structure has become more comprehensible in relation to the reference needs and reference skills of the target users. Therefore, a functional approach, derived from the theory of lexicographic functions, has emerged to be the best course to dictionary typology and dictionary structure (Gouws and Prinsloo 2005: 55). On this account, it needs to be emphasised that it is not merely the conventional structure which makes one dictionary superior to another, or the size which makes a dictionary superior to a glossary, but the ability to exploit structural features so that more information becomes available and accessible.

\subsection{The theory of lexicographic functions}

The main feature of the theory of lexicographic functions is that it is user-oriented. As literature on this theory and its application is now abundantly available (cf. Bergenholtz and Tarp 1995, 2003; Tarp 2000, 2005, 2008; Gouws 2007), no elaborate exposition of it will be given here. It suffices to reiterate that the theory takes into account the characteristics of specific users, the typical usersituations, the typical problems users experience in such situations, their needs to address such problems and finally, the lexicographic functions of the available and prospective dictionaries regarding the assistance users may find to solve their problems. The functions are divided into cognitive and communication-oriented functions. Cognitive functions are those by means of which the dictionary provides assistance which enhances or improves the user's knowledge, be it general, cultural or linguistic (cf. Bergenholtz and Tarp 1995, 2003; Tarp 2000, 2005, 2008). Communication-related functions address problems 
users encounter in communication-related situations such as text production (writing and speaking), text reception (reading and listening) and translation (cf. Bergenholtz and Tarp 1995, 2003; Tarp 2000, 2005, 2008). According to this theory, nothing is taken for granted, be it the inclusion of data or the methods of presentation in a dictionary or even dictionary typology. The insights drawn from the theory of lexicographic functions affirm the importance of LSP dictionaries in the African languages.

\subsubsection{Text reception in English}

In many African societies, the use of English as the main language in both the public and the private formal sectors is seen as a hindrance to maximum and successful participation of the majority of people who are native speakers of indigenous languages. The concerns are even more serious in education. In addition to a variety of factors, it is true that some learners do not perform well because they are not proficient in the language of instruction. They do not understand the educators and the textbooks they read. Code-switching and code-mixing in classrooms is one indicator that a native language may be the point of departure for some learners in improving general English proficiency and acquiring various LSPs used in the practice and study of specific subjects (Paxton 2009). In view of this, LSP dictionaries may be produced in indigenous languages so that they serve as communication bridges for learners who have very limited command of English for academic and specific purposes. The inclusion of translation equivalents, definitions and/or explanatory notes in their indigenous languages against English LSP elements may solve text reception problems. Most multilingual glossaries being produced for higher education learners in South Africa have this in mind, although the inclusion of data types in them indicates the different degrees to which the role of indigenous languages in English-dominated language-in-education policies is understood.

\subsubsection{Text production in indigenous languages}

In indigenous African language activism, there are some who believe that in education and other sectors indigenous languages should be elevated to the status of English. Although such a radical approach needs rethinking, it may be noted that its success presupposes a large-scale production of textbooks and other teaching materials. The task would be difficult without LSP dictionaries which take into account written text production as its function. A more practical approach to language planning would rather begin by encouraging the use of indigenous African languages in speakers' own studies, be it literature or linguistics. Compared to the dictionary of music terms which is the first and currently the only LSP dictionary in Ndebele, the production of a dictionary of linguistic and literary terms in Ndebele on such a basis would have had a more 
significant impact on the status and functional elevation of Ndebele in Zimbabwe. It has proven difficult for Ndebele to function maximally as a study subject in schools, colleges and universities, because of an acute shortage of Ndebele textbooks and other teaching materials. While the monolingual general dictionary, Isichazamazwi SesiNdebele (Hadebe et al. 2001), contributed to the standardisation of the orthography, vocabulary and terminology (Hadebe 2006), which would in turn facilitate text production, its limited scope and depth on various LSPs indicate that there is a vacuum in LSP lexicography to be filled in Ndebele regarding the text production function in the various specialised subject areas.

\subsubsection{Translation of texts into the indigenous languages}

The dominance of English and the now urgent multilingual agenda in many African societies, as well as globalisation which necessitates intercultural communication have all increased the role of translation, especially from English into the indigenous African languages. The South African constitution, for example, is available in all eleven official languages. This applies to other government documents and documents produced by non-governmental organisations on issues such as human rights and HIV/AIDS which need to be translated into the languages understood by the people. As indicated by Moropa's (2004) article, translators need tools to help them deal with a variety of challenges they encounter within the range of finding the right translation equivalents and their collocations. Contrary to her assertion that dictionaries need to be used as the last resort, they may actually serve as the translator's first source of consultation, and for this to be worthwhile, better dictionaries need to be produced. All that is required are dictionaries compiled with the translation task as one of their functions. If a dictionary of business, commerce or finance was to be produced with isiXhosa as one of the treated languages, it would do well to consider translation of financial texts from English into isiXhosa as its function. Such a dictionary may be more effective than a parallel corpus, given the various possibilities available for lexicographers, including clear meaning discrimination for translation equivalents and the presentation of subject fields in the front matter.

\subsubsection{Provision of special, encyclopaedic and cultural information}

If LSP dictionaries may solve some of the communication-related problems briefly discussed in the foregoing, the dictionaries would, one way or another, provide special, encyclopaedic and cultural information about their respective subject fields. This does not mean that an LSP dictionary would automatically realise these cognitive functions by providing information relevant to text production, text reception and translation. These dictionaries may, in the mould of 
polyfunctional dictionaries, provide such information which may facilitate the realisation of both communication-oriented and cognitive functions, but a very clear prioritisation strategy would have to ensure that certain functions prevail over others in particular LSP dictionaries.

The Zimbabwean LSP dictionaries produced under the auspices of the African Languages Lexical (ALLEX) Project at the African Languages Research Institute (ALRI) provide both specialised and encyclopaedic information about concepts of their respective subject areas. The music terms dictionaries in Ndebele and Shona, respectively Isichazamazwi SezoMculo (Nkomo and Moyo 2006) and Duramazwi reMimhanzi (Mheta 2005), for example, do not restrict themselves to the traditional lexicographic definitions (Wiegand 1984: 17). Instead, definitions provide information on the term, the concept represented and even pictorial illustrations of concepts such as music instruments and costumes. In this way, users obtain terminological, special and encyclopaedic information. Similarly, it may be instructive that multilingual glossaries produced by institutions of higher learning in South Africa also provide adequate specialised and encyclopaedic information about subject-field concepts since it is their main endeavour to facilitate concept literacy in indigenous languages. Otherwise most of those that are already available have betrayed this goal by simply providing equivalents in the indigenous languages and very brief definitions, in line with some of the principles of terminological definitions which also argue for the univocity of terms (one-concept-one definition). The limitations of traditional and terminological defining principles for pedagogical LSP lexicography have been demonstrated by Carstens (1997) in an article on a multilingual dictionary of Chemistry for institutions of higher education in South Africa and are also discussed in Fuertes-Olivera and Arribas-Baño (2008).

Given that some subject fields are shaped by historical, religious and practical factors which are specific to certain countries or regions, cultural information also needs to be considered in LSP dictionaries. A law dictionary in South Africa would be a good example of an LSP dictionary in which cultural information would have to be considered. The foundations of South African law dictate that a dictionary of law for South African users would be different from a law dictionary in a country with a different legal system, including the European sources of South African law which do not have South African common law as its constituent.

The cultural factor came into play during the production of all Zimbabwean Shona and Ndebele LSP dictionaries. The two music terms dictionaries mentioned earlier, the Shona biomedical terms dictionary (Mpofu et al. 2004) and the Shona dictionary of linguistic and literary terms (Chimhundu and Chabata 2006) all had to be sensitive to the cultural peculiarities of the subject fields in the Zimbabwean context. This included striking a balance in the selection of lemmata and the provision of more encyclopaedic definitions. A careful selection of defining vocabulary was also required, especially in the case of the biomedical terms dictionary where the dilemma with respect to the treatment 
of taboo and offensive terms emerged (Mpofu and Mangoya 2005: 129-130). The compilers of the biomedical terms dictionary also had to consider that the young generation of doctors have limited knowledge and vocabulary related to traditional health practices and beliefs (Mpofu and Mangoya 2005: 118). The importance of providing cultural information in LSP dictionaries for African languages has also been underlined by Smit (1998) in her proposed multilingual and multicultural music dictionary for South African music education. All these factors indicate that LSP dictionaries in the African languages have cognitive functions not necessarily limited to assisting users with specialised information, but also with encyclopaedic as well as cultural information.

\section{Conclusion}

The main objective of this article has been to affirm the role of LSP dictionaries in African languages. As stated in the introduction, this role is constituted by a collective of lexicographic functions that the dictionaries may fulfil, according to the theory of lexicographic functions. The relevance of LSP dictionaries in the African languages is not necessarily derived from their desired status and functional elevation to the level of languages such as English as this may take too long to be realised. Even in the present context of the continued domination of languages such as English as the main languages of practice and teaching in various subject fields, indigenous African languages may serve as auxiliary media. LSP dictionaries in these languages may be useful for functions such as text production, text reception, translation and acquisition of specialised, encyclopaedic and cultural knowledge. However, in the long term, the dictionaries will prove useful in supporting the status and functional elevation of the indigenous languages. It is important that the production of the prospective dictionaries draw guidance from theoretical lexicography so that they are userfriendly and able to satisfy the needs of the users. If LSP dictionaries in the African languages are produced which serve the functions discussed in this article, then disillusioned language practitioners and general users will only realise that what is currently amiss is the availability and quality of the dictionaries and not dictionaries per se. Subsequently, it will emerge that lexicography in general has the potential of addressing most of the cognitive and communication needs confronting African societies in this information age.

\section{Acknowledgement}

I am sincerely grateful to Prof. Sven Tarp for his comments during a conversation after the presentation of this paper at the AFRILEX conference, as well as for comments by Dr Emmanuel Chabata and Prof. Rufus Gouws on an earlier version of the article. 


\section{References}

Al-Kasimi, A.M. 1977. Linguistics and Bilingual Dictionaries. Leyden: E.J. Brill.

Awak, M.K. 1990. Historical Background, with Special Reference to Western Africa. Hartmann, R.R.K. (Ed.). 1990: 8-18.

Béjoint, H. 2000. Modern Lexicography. Oxford: Oxford University Press.

Béjoint, H. 2010. The Lexicography of English. Oxford: Oxford University Press.

Bergenholtz, H. 2003. User-oriented Understanding of Descriptive, Proscriptive and Prescriptive Lexicography. Lexikos 13: 65-80.

Bergenholtz, H. and S. Nielsen. 2006. Subject-field Components as Integrated Parts of LSP Dictionaries. Terminology 12(2): 281-303.

Bergenholtz, H. and S. Tarp. 1995. Manual of Specialised Lexicography. Amsterdam/Philadelphia: John Benjamins.

Bergenholtz, H. and S. Tarp. 2003. Two Opposing Theories: On H.E. Wiegand's Recent Discovery of Lexicographic Functions. Hermes, Journal of Linguistics 31: 171-196.

Bowker, L. and J. Pearson. 2002. Working with Specialized Language: A Practical Guide to Using Corpora. London/New York: Routledge.

Burkhanov, I. 2004. Requirements for an "Ideal" Bilingual L1-L2 Translation Oriented Dictionary. Lexikos 14: 17-32.

Busane, M. 1990. Lexicography in Central Africa: The User-Perspective, with Special Reference to Zaire. Hartmann, R.R.K. (Ed.). 1990: 19-35.

Carstens, A. 1997. Issues in the Planning of a Multilingual Explanatory Dictionary of Chemistry for South African Students. Lexikos 7: 1-24.

Chabata, E. 2007. The African Languages Research Institute: A Milestone in the Development of African Languages. Lexikos 17: 278-291.

Chimhundu, H and E. Chabata. 2006. Duramazwi reDudziramutauro neUvaranomwe. Gweru: Mambo Press.

Ella, E.M. 2007. A Theoretical Model for a Fang-French-English Specialised Multivolume School Dictionary. Unpublished D.Litt. Dissertation. Stellenbosch: University of Stellenbosch.

Fischer, A. et al. 1985. English-Xhosa Dictionary. Oxford: Oxford University Press.

Fuertes-Olivera, P.A and A. Arribas-Baño. 2008. Pedagogical Specialised Lexicography. The Representation of Meaning in English and Spanish Business Dictionaries. Amsterdam/Philadelphia: John Benjamins.

Gouws, R.H. 1996. A Sequence for Meeting Lexicographic Needs. Lexicography as a Financial Asset in Multilingual South Africa: 97-110. Pretoria: Department of Arts, Culture, Science and Technology.

Gouws, R.H. 2001. Lexicographic Training: Approaches and Topics. Emejulu, J.D. (Ed.). 2001. Éléments de lexicographie gabonaise. Tome I: 58-94. New York: Jimacs-Hillman.

Gouws, R.H. 2003. Towards the Formulation of a Theoretically Motivated Model for the National Lexicography Units in South Africa. Hartmann, R.R.K. (Ed.). 2003. Lexicography: Critical Concepts: 218-246. London/New York: Routledge.

Gouws, R.H. 2004. Monolingual and Bilingual Learners' Dictionaries. Lexikos 14: 264-274.

Gouws, R.H. 2007. A Transtextual Approach to Lexicographic Functions. Lexikos 17: 77-87. 
Gouws, R.H. and D.J. Prinsloo. 2005. Principles and Practice of South African Lexicography. Stellenbosch: SUN PReSS.

Hadebe, S. 2006. The Standardisation of the Ndebele Language through Dictionary-making. Harare/Oslo: The ALLEX Project.

Hartmann, R.R.K. (Ed.). 1984. LEX'eter '83 Proceedings. Papers from the International Conference on Lexicography at Exeter, 9-12 September 1983. Tübingen: Max Niemeyer.

Hartmann, R.R.K. (Ed.). 1990. Lexicography in Africa. Progress Reports from the Dictionary Research Centre Workshop at Exeter, 24-25 March 1989. Exeter: University of Exeter Press.

Hartmann, R.R.K. 2005. Lexicography and its Interdisciplinary Contacts with Special Reference to Onomasiology. Lexikos 15: 70-89.

Madiba, M. 2004. Parallel Corpora as Tools for Developing the Indigenous Languages of South Africa with Special Reference to Venda. Language Matters 35(1): 133-147.

Mafela, M.J. 2005. Meaning Discrimination in Bilingual Venda Dictionaries. Lexikos 15: 276-285.

McArthur, T. 1986. Worlds of Reference: Lexicography, Learning and Language from the Clay Tablets to the Computer. Cambridge: Cambridge University Press.

Mheta, G. (Ed.). 2005. Duramazwi reMimhanzi. Gweru: Mambo Press.

Moropa, K. 2004. A Parallel Corpus as a Terminology Resource for Xhosa: A Study of Strategies Used to Translate Financial Texts. Language Matters 35(1): 162-178.

Mpofu, N. and E. Mangoya. 2005. The Compilation of the Shona-English Biomedical Dictionary: Problems and Challenges. Lexikos 15: 117-131.

Mpofu, N. et al. (Eds.) 2004. Duramazwi reUrapi neUtano. Gweru: Mambo Press.

Nkomo, D. 2008. Towards a Theoretical Framework for LSP Lexicography in Ndebele with Special Reference to a Dictionary of Linguistic and Literary Terms. Unpublished M.Phil. Thesis. Stellenbosch: University of Stellenbosch.

Nkomo, D. and N. Moyo (Eds.). 2006. Isichazamazwi SezoMculo. Gweru: Mambo Press.

Paxton, M.I.J. 2009. It's easy to learn when using your home language but with English you need to start learning the language before you get to the concept: Bilingual Concept Development in an English Medium University in South Africa. Journal of Multilingual and Multicultural Development 30(4): 345-359.

Pinchuck, I. 1977. Scientific and Technical Translation. London: André Deutsch.

Sinclair, J.M. 1984. Lexicography as an Academic Subject. Hartmann, R.R.K. (Ed.). 1984: 3-12.

Smit, M. 1996. Wiegand's Metalexicography as a Framework for a Multilingual, Multicultural, Explanatory Music Education Dictionary for South Africa. Unpublished D.Phil. Thesis. Stellenbosch: University of Stellenbosch.

Smit, M. 1998. A Multilingual, Multicultural, Explanatory Music Education Dictionary for South Africa - Using Wiegand's Metalexicography to Establish its Purposes, Functions and Nature. Lexikos 8: 88-97.

Smit, M. 2002. The Systematic Development of Wiegand's Metalexicography as Reflected in Kleine Schriften. Lexikos 12: 290-310.

Swanepoel, P. 2008. Towards a Framework for the Description and Evaluation of Dictionary Evaluation Criteria. Lexikos 18: 207-231.

Tarp, S. 2000. Theoretical Challenges to Practical Specialised Lexicography. Lexikos 10: 189-208.

Tarp, S. 2002. Basic Elements of a Lexicographic Theory. Emejulu, J.D. (Ed.). 2002. Éléments de lexicographie gabonaise. Tome II: 7-20. New York: Jimacs-Hillman. 
Tarp, S. 2002a. Translation Dictionaries and Bilingual Dictionaries. Two Different Concepts. Journal of Translation Studies 7: 59-84.

Tarp, S. 2004. Basic Problems of Learners' Lexicography. Lexikos 14: 222-252.

Tarp, S. 2005. The Pedagogical Dimension of a Well-conceived Specialised Dictionary. Iberica. Journal of European Languages for Specific Purposes 10: 7-21.

Tarp, S. 2008. Lexicography in the Borderland between Knowledge and Non-knowledge: General Lexicographical Theory with Particular Focus on Learner's Lexicography. Tübingen: Max Niemeyer.

Tarp, S. 2010. Reflections on the Academic Status of Lexicography. Lexikos 20: 450-465.

Tarp, S. and R.H. Gouws. 2008. A Lexicographic Approach to Language Policy and Recommendations for Future Dictionaries. Lexikos 18: 232-255.

Wababa, Z., K. Welman and K. Press (Eds.). 2010. Isichazi-magama seziBalo Sezikolo. Cape Town: Cambridge University Press.

Wiegand, H.E. 1984. On the Structure and Contents of a General Theory of Lexicography. Hartmann, R.R.K. (Ed.). 1984: 13-30.

Yong, H. and J. Peng. 2007. Bilingual Lexicography from a Communicative Perspective. Amsterdam/ Philadelphia: John Benjamins.

Young, D. et al. 2005. Understanding Concepts in Mathematics and Science. A Multilingual Learning and Teaching Resource Book in English, Xhosa, Afrikaans and Zulu. Volume 1. Cape Town: CALLSSA, School of Education.

Young, D. et al. 2009. Understanding Concepts in Mathematics and Science. A Multilingual Learning and Teaching Resource Book in English, Xhosa, Afrikaans and Zulu. Volume 2. Cape Town: CALLSSA, School of Education. 